\title{
To Open or Close? COVID-19, Mosques and the Role of Religious Authority within the British Muslim Community: A Socio-Legal Analysis
}

\author{
Amin Al-Astewani
}

check for updates

Citation: Al-Astewani, Amin. 2021. To Open or Close? COVID-19,

Mosques and the Role of Religious Authority within the British Muslim Community: A Socio-Legal Analysis. Religions 12: 11. https://dx.doi.org/ $10.3390 /$ rel12010011

Received: 16 November 2020 Accepted: 16 December 2020 Published: 24 December 2020

Publisher's Note: MDPI stays neutral with regard to jurisdictional claims in published maps and institutional affiliations.

Copyright: (c) 2020 by the author. Licensee MDPI, Basel, Switzerland. This article is an open access article distributed under the terms and conditions of the Creative Commons Attribution (CC BY) license (https: / / creativecommons.org/ licenses/by/4.0/).
Law School, Lancaster University, Lancaster LA1 4YW, UK; a.al-astewani@lancaster.ac.uk

\begin{abstract}
A whirlwind of developments have unfolded in the UK since the emergence of the COVID19 pandemic, which has subsequently instigated an intensely animated debate among British Muslim religious leaders about the contentious and sensitive topic of mosque closure, producing a rich and sophisticated spectrum of responses. These responses emerged within the dramatic global background of an imminent closure of Islam's most cherished mosque to international pilgrims, namely the sacred precinct in Mekkah. The stakes were, therefore, high for British Muslim religious leaders considering mosque closure, facing the stark dilemma of compromising the sacrosanct status of the mosque and congregational worship in Islam or putting the lives of British Muslims in their hundreds of thousands at risk. This paper seeks to analyze the role of religious authority within the British Muslim community through the lens of the responses of the community's religious leaders to the COVID-19 closure of mosques. It builds upon a Special Issue published by this journal on leadership, authority and representation in British Muslim communities. The issue of COVID-19 mosque closure in the UK presented an excellent case study for this paper's analysis, manifesting as it does the dynamic way in which religious authority in the British Muslim community continues to evolve. This paper thus seeks to use this case-study to further enrich the literature on this topic.
\end{abstract}

Keywords: COVID-19; British Muslim Community; British mosques; religious authority; religious leadership; Islamic law

\section{Introduction}

At the time of writing, England has just entered its second COVID-19 lockdown. To the deep dismay of Muslim religious leaders, this lockdown has included the closure of places of worship, as was the case with the first lockdown. In response, over 500 mosques under the leadership of the prominent national council of Muslim scholars "Wifaqul Ulama" have signed a letter addressed to Prime Minister Boris Johnson requesting that congregational prayers in mosques are allowed to continue during the lockdown. ${ }^{1}$ This development epitomizes the whirlwind of developments that have unfolded in the UK since the emergence of the COVID-19 pandemic, which has subsequently instigated an intensely animated debate among British Muslim religious leaders about the contentious and sensitive topic of mosque closure, producing a rich and sophisticated spectrum of responses. These responses emerged within the dramatic global background of an imminent closure of Islam's most cherished mosque to international pilgrims, namely the sacred precinct in Mekkah. ${ }^{2}$ The stakes were, therefore, high for British Muslim religious leaders considering mosque closure, facing the stark dilemma of compromising the sacrosanct status of the mosque and congregational worship in Islam or putting the lives of British Muslims in their hundreds of thousands at risk.

\footnotetext{
1 See (5Pillars 2020a).
}

2 See (Chitwood 2020). 
The history of mosques in the UK is inextricably interwoven with Muslim migration to the UK. Following a major migration wave after the Second World War, the 2nd half of the 20th-century witnessed a sudden rise in the number of British Muslims as well as their concentrated efforts to institutionalize their religion at a community level, having settled permanently since their migration (Asad 1990; Ansari 2004; Bowen 2013). Indeed, there were only 13 mosques registered with the registrar as places of worship in 1963. This had increased to 338 registered mosques by 1985 (Nielsen 1992). Since 1985, this number has continued to increase: in 2009, there was a reported 870 registered mosques in England and Wales (Littler 2011). The Muslim practice of establishing mosques in any new place of settlement is inspired by the prophetic legal precedent, with the Prophet's mosque in Madinah being established almost immediately after the first Muslims migrated to Madinah to form an Islamic community (Al-Buti 2006). The Prophet's mosque went on to become the spiritual hub of the new Islamic community, and mosques ever since have enjoyed a sacrosanct status at the social epicenter of Islamic communities and played the fundamental role of delivering the community's most important religious services (McLoughlin 1998; Zaimeche 2002). The increase in the number of British mosques has, therefore, understandably correlated with the growing size of the British Muslim community. According to the 2011 census, Muslims now form 4.8\% of the population in England and Wales. Their number had increased from 1.55 million in 2001 to 2.71 million in 2011. The Muslim population is significantly larger than all other non-Christian denominations put together. $68 \%$ of this Muslim population is Asian, $47 \%$ are UK-born, and $73 \%$ state their only national identity is British (Ali 2015).

This paper seeks to analyze the role of religious authority within the British Muslim community through the lens of the responses of the community's religious leaders to the COVID-19 closure of mosques. It builds upon a Special Issue published by this journal on leadership, authority and representation in British Muslim communities, to which the author contributed with a paper on the quasi-judicial authority of British Shariah tribunals (Al-Astewani 2019). This special issue emerged from a momentous conference in 2019 hosted by Cardiff University's Center for the Study of Islam, which gathered together key religious figures from the Muslim community along with academics to critically assess the phenomenon of religious authority within the British Muslim community. The issue of COVID-19 mosque closure in the UK thus presented an excellent case study for this paper's analysis, manifesting as it does the dynamic way in which religious authority in the British Muslim community continues to evolve. Writing after the emergence of COVID-19, the Special Issue's chief editors stated in this regard: "the debates it sparked in Muslim communities across the UK, particularly on the question of voluntary mosque closures, brought into sharp relief many of the issues of leadership, authority, and representation addressed herein" (Gilliat-Ray and Timol 2020).

This paper is among the first substantive attempts to assess the implications of COVID19 on religious authority within the British Muslim community. One of the only other such attempts was a valuable blog-post published in April 2019 by the Journal of British Muslim Studies and written by Timol, another author who contributed to this journal's Special Issue with an article on the Tablighi Jama'at in Britain (Timol 2020b). The paper thus hopes to further enrich the developing literature on this topic. In terms of methodology, the paper has adopted a socio-legal approach in its analysis. The socio-legal research method enhances and expands upon the traditional black-letter analysis of legal phenomena by placing such phenomena within their theological, historical, social, political and economic contexts (Twining 1997; Tamanaha 2001; Cownie et al. 2003; Peterson 2003). By viewing and analyzing such phenomena from a variety of perspectives, the socio-legal research method helps to shed new light and bring fresh perspectives to bear on the nature and function of such phenomena. After critiquing the methodological approaches traditionally adopted by academics in the field of law, Harris expounds on the value of the socio-legal approach in the following words: 
We have seen that there is no one way of undertaking legal study: whilst all the various approaches may have something useful to offer, none has yet managed to produce an analysis of law and legal systems which answers all the many and varied questions which students and researchers might want to ask about this fascinating subject. The perspective taken in this present book is that an understanding of the law cannot be acquired unless the subject matter is examined in close relationship to the social, economic and political contexts in which it is created, implemented and maintained. (Harris 2007)

This particular research method has been adopted for this paper out of recognition of the fact that religious leaders within the British Muslim community engage with both Islamic law and English law within social spaces that have been directly shaped and influenced by a variety of sociological factors such as religion, culture, demography and politics. Such factors must be studied and taken into account in order to ensure that a traditional black-letter analysis of law is placed within the correct context and perspective. In order to further enhance the analysis, an attempt was made whenever possible to engage in a comparative analysis of parallels that exist between Islamic law and English law in relation to the paper's discourse on religious authority.

\section{A Colorful Crescent: COVID-19, Mosques and the Spectrum of Responses within the British Muslim Community}

The spectrum of responses to the COVID-19 crisis from the British Muslim community may be classified into two broad categories for the purpose of analysis. The first category may be labeled the "activist" response and encompasses what may be generally termed Non-Governmental Organizations (NGOs) such as the Muslim Council of Britain, the British Islamic Medical Association and the Islamic Human Rights Commission. The use of the term NGO in this context is justified by the fact that such organizations, while bearing distinctively religious affiliations, are nevertheless nonprofit civil societies that serve social and political goals like any other NGO (as shall be highlighted below). The second category may be labeled the "academic" response and encompasses organizations as well as other social networks that are primarily characterized by their scholarly or clerical credentials. As shall be seen, each set of responses bears distinguishing hallmarks, which thereby portrays the dynamic and diverse ways in which religious authority is manifested in the British Muslim community.

\subsection{The Activists}

Three institutions were chosen to illustrate the "activist" spectrum of responses. Alongside the fact that these were among the most prominent and widely publicized of such responses on media platforms, each institution also represents an important segment of the British Muslim community, thus rendering their responses most pertinent for analysis. The Muslim Council of Britain (MCB) is the largest of the three organizations and was formed in 1997 (Radcliffe 2004; Pedziwiatr 2007). It describes itself as the UK's largest Muslim umbrella organization whose members include mosques, schools, charitable associations and professional networks (Burford 2012; Khan et al. 2020). Mosques, in particular, play a central role in the MCB's agenda. One of its most high-profile projects is the "Visit My Mosque Day", which was launched in 2005 and by 2018 enjoyed the participation of over 200 mosques across the UK (Arif 2020). Out of the three organizations, the MCB, therefore, stands out as a key influencer over UK mosques, albeit the fact that its influence also goes beyond this and into the heart of the Muslim community due to its comprehensive range of networks.

As a professional network, the British Islamic Medical Association (BIMA) is a member of the MCB. Founded in 2013, BIMA describes itself as an organization that strives to "unite, inspire and serve Muslim healthcare professionals in the UK". ${ }^{3}$ Its response to COVID-19

3 See (British Islamic Medical Association 2020a). 
is significant for two reasons. The first is that it is one of the most prominent professional networks in the British Muslim community, with healthcare professionals forming one of the community's largest professional segments. The second is that the medical expertise it enjoys in the context of a health crisis enhances its response with distinctive legitimacy in the eyes of the Muslim community, particularly those members of the community who hold professional advice in high regard even at the expense of religious advice. BIMA's collaboration with prominent British medical organizations such as the British Heart Foundation and Cancer Research UK adds to the legitimacy of its views on public health events. ${ }^{4}$

Like the MCB, the Islamic Human Rights Commission was also formed in 1997 during the historical period of concentrated institutionalization within the British Muslim community (Klausen 2005). The IHRC describes itself as an NGO that promotes "justice for all peoples regardless of their racial, confessional or political background. ${ }^{\prime 5}$ As a professed Human Rights organization, it is the most outwardly "activist" of the three organizations. It, therefore, acts as a good representative of the dedicated activist segment within the British Muslim community. Its Special Consultative Status with the Economic and Social Council of the United Nations also enhances the authority which it bears, particularly within this segment of the community.

It can now be seen that these three organizations, despite differing in the particular focus of their work, all share the common characteristic of exerting religious influence through the paradigm of activism. This is clearly noticeable in the way that such organizations characterize themselves primarily in activist rather than theological terms. This includes common usage of terms such as "independent", "democratic", "non-governmental", "notfor-profit" and "grassroots", terms which are typically used by NGOs regardless of their religious affiliations. If theological terms were used, these tended to be featured in a less prominent fashion and tailored in any case towards the activist paradigm. Taking the IHRC as an example, it is only towards the very end of the "About Us" section on their website that it is stated, "our inspiration derives from the Qur'anic injunctions that command believers to rise up in defense of the oppressed." 6 This common characteristic, which represents a hallmark of these organizations, is reflected in the nature of their responses to the COVID-19 crisis and is therefore important to note in the context of the forthcoming analysis.

\subsection{The Academics}

Three organizations were chosen to depict the "academic" range of responses: the British Board of Scholars and Imams, Wifaqul Ulama and Islam21C. All three of these organizations were prominently engaged in the theological and legal dialog which unfolded within the Muslim community in relation to COVID-19. They are also well-representative of the broad spectrum of theological affiliations that feature among members of the community across the UK, thus making them apt case-studies for analysis in this context.

The British Board of Scholars and Imams (BBSI) may be characterized as the most progressive of the three organizations. Its formation began with an informal meeting of Scholars and Imams in 2013 who sought to establish an institution that could foster dialog on theological, legal and spiritual matters within the Muslim community. ${ }^{7}$ It describes itself as a "National Assembly of Imams, Scholars and Islamically literate Muslim Academics" whose aim is to "facilitate intra Muslim dialog on Theology, Jurisprudence and Community Welfare." ${ }^{8}$ Its list of council members show-cases an impressively diverse range of over

\footnotetext{
See (Akhter 2017; Oldham Evening Chronicle 2020).

See (The Islamic Human Rights Commission 2020a).

See (The Islamic Human Rights Commission 2020a).

See (BBSI 2020a).

See (BBSI 2020a).
} 
50 influential religious personalities in the Muslim community, including Imams, scholars and Muslim academics. ${ }^{9}$

A number of observations can be made when taking into account the biographies of the Board's council members. The first is that ancient centers of Islamic learning such as Al-Azhar University in Egypt and Al-Qarawiyyin University in Morocco continue to attract members of the Muslim community aspiring to become religious leaders, as is reflected by reference to such institutions in the biographies of the council members as proof of clerical qualifications. Al-Azhar and Al-Qarawiyyin are among the oldest educational institutions in the Islamic tradition, and their influence over religious leaders in the British Muslim community portrays the continuing currency of this classical tradition in the modern era (Brown 2011; Hardaker 2012). Indeed, it is a reference to this classical tradition, which plays an important role in legitimizing the position of religious leaders towards public crises in the eyes of the community. This does not mean, however, that such religious leaders ignore the importance of engaging with modernity. On the contrary, the second observation to note from the biographies is the combination by most of the council members between classical and modern learning. Several of the council members have postgraduate qualifications from Western universities in a variety of fields, while others are also qualified professionals in fields as diverse as psychiatry, law, dentistry and finance.

This leads to the third observation, which is that many of the council members also hold positions as academics or researchers in different UK universities. Some of these members have combined this with traditional Islamic learning, while others have been invited to join the Board solely by virtue of their academic roles as Muslim members of the community. It is pertinent to note in this regard that nine council members attended and contributed to the conference organized by Cardiff University's Center for the Study of Islam in 2019 on Leadership, Authority and Representation in British Muslim Communities. Taken together, both these observations highlight the significantly progressive make-up of the BBSI and the importance that the Board attaches to engaging with modernity in the dialogs which it facilitates. The final observation to note is that the council members represent the full spectrum of theological affiliations in the Muslim community, including orthodox, modernist and liberal strands of such affiliations. This fact is explicitly celebrated by the Board, which refers to itself as a "nonpartisan network dedicated to a cooperation based on the principle of unity of purpose, as opposed to the uniformity of opinion."10 This characteristic marks out the BBSI from most other academic networks within the British Muslim Community, which almost always tend to be organized along sectarian lines.

Wifaqul Ulama (WU) is much more traditional in outlook than the BBSI. Its Arabic name means "the consensus of the scholars", and it describes itself as a "body which seeks to bring Muslims Scholars and Laymen together to work for the betterment of Muslims in Britain." 11 While this description indicates a non-sectarian attitude, a closer assessment reveals that WU is, in fact, a Deobandi organization in terms of theological affiliation. This is clear from the biographies of the scholars who are members of the organization. ${ }^{12}$ This renders the role of WU particularly pertinent because of the widespread influence of Deobandi scholars in the British Muslim Community. Indeed, Deobandi religious leaders are responsible for one of the most established networks of religious seminaries in the UK, and they enjoy powerful authority in the conservative and tight-knit communities, which they have also been instrumental in developing (Gilliat-Ray 2005; Sidat 2018). The importance of WU's role is also enhanced by the entrenched relationship between Deobandi religious leaders and the Tablighi Jama'at, despite the latter's focus on missionary activity rather than scholarship and education (Timol 2019). The Tablighi Jama'at also enjoys significant influence over the British Muslim community through its national networks

\footnotetext{
See (BBSI 2020b).

See (BBSI 2020a).

See (Wifaqul Ulama 2020a).

See (Wifaqul Ulama 2020b).
} 
of affiliated mosques and community centers (Ahmed 2019). It must be emphasized that while WU is affiliated with the Deobandi community, it is not by any means the only mouthpiece of the community's religious leaders. This was clearly illustrated in the response of Deobandi religious leaders to the COVID-19 crisis, which was expressed through a number of informal mediums alongside the more institutionalized medium of $\mathrm{WU}$, as shall be seen in the forthcoming analysis.

Islam $21 \mathrm{c}$ may be characterized as the most technologically astute and politically engaged of the three organizations. Its main focus is the provision of religious guidance attuned to the modern context through a variety of electronic media formats. Its guidance thus covers a diverse range of social topics, including finance, history, health and management. It also offers a comprehensive analysis of current affairs through a theological lens (Amin 2019). Islam21c's main audience within the Muslim community is young professionals, and it enjoys a wide following in this regard with over 250,000 fans on its Facebook page and over 20,000 subscribed to its weekly electronic newsletters (Amin 2019). Dr. Haitham Al-Haddad is the pioneering religious leader behind Islam21c. $\mathrm{He}$ is described by the organization as a jurist who studied the Islamic tradition for over 20 years under the tutelage of scholars in Saudi Arabia, following which he earned a doctorate from the School of Oriental and African Studies with his doctoral thesis exploring Islamic jurisprudence concerning Muslim minorities. This combination of religious and academic studies gives him the ability to provide 'complex theories which address the role of Islamic jurisprudence within a western environment while also critically reanalyzing the approach of Islamic jurists in forming legal rulings (ifta') within a western socio-political context". ${ }^{13}$ This emphasis on a nuanced jurisprudential approach that carefully considers the socio-political context when issuing religious verdicts is particularly pertinent as it was Al-Haddad who expounded Islam21c's primary response to the COVID-19 crisis.

\subsection{The Influencers from Abroad}

There are two sociological reasons for considering the impact of influence from abroad on religious leadership within the British Muslim Community and the way such influence affects their attitudes towards socio-political events. The first stems from the status of British Muslims as a migrant community, which gives rise to strong cultural bonds with the mosaic of home countries from which British Muslims hail (Timol 2020a). The dynamic strength of these cultural bonds means that their influence even extends to later-generation British Muslims born and bred in the UK, as well as native converts who integrate within the community (Hopkins 2009). The second relates to the theological bond of the community with the Muslim world in general, commonly recognized as the supra-national affiliation to the worldwide "Ummah" of believers (Ahmad and Evergeti 2010). These two reasons render influence from abroad pertinent for analysis when exploring the pathways of religious authority in the community and how they are manifested. The colonial roots of Shariah tribunals in the UK is a particularly illustrative case-study of this phenomenon. South Asian Muslims migrants who decided to establish the first such tribunals in the UK were simply expanding on the colonial experience they had engaged within their home countries, where the British government had allowed them to form an alternative judicial system and privately manage their affairs without intervention from colonial administration (Al-Astewani 2019). This influence manifests particularly through the Dissolution of Muslim Marriages Act 1939, a colonial piece of legislation that offered the migrant community a concrete legal framework for regulating judicial divorce, which takes into consideration the sensibilities of Islamic law (Al-Astewani 2019).

In the context of this paper's analysis, influence from abroad on the responses of the British Muslim community to COVID-19 may be classified into "international" influence from the Muslim world and "regional" influence from Muslim communities in other Western states. Beginning with the "international" influencers, three groups were particularly

13 See (Islam21c.com 2020a). 
prominent in the discourse that unfolded in the UK. The first is Deobandi religious leaders in the Indian subcontinent, which is considered the heartland and headquarters of the worldwide Deobandi community (Reetz 2007). These religious leaders wield significant influence over the Deobandi community in the UK (Siddiqi 2018). A particularly significant figure in this regard is Mufti Taqi Usmani, one of the leading intellectuals of the modern Deobandi movement which frequently features as a teacher and mentor in the biographies of British Deobandi religious leaders and has also acted as a judge on the Shariat Appellate Bench of the Pakistani Supreme Court (Pemberton 2009). The second group is members of the United Arab Emirates (UAE) Fatwa Council. This council, whose role is to issue legal verdicts concerning matters which affect Muslims worldwide, is headed by the prominent Mauritanian scholar Abdullah Bin Bayyah (Al-Azami 2019). Its influence over Western Muslim communities lies in the inclusion among the council's members of Hamza Yusuf, one of Bin Bayyah's most high profile students. Yusuf has been justifiably described by the Guardian as "arguably the West's most influential Islamic scholar," and his influence transcends his home country of America to encompass the Western Muslim community as a totality. ${ }^{14}$ This influence is reflected in the fact that the council's key legal verdicts are translated into fluent English and widely circulated in the West via Yusuf's powerful media platforms, with the council's legal verdict on COVID-19 no exception to this rule. ${ }^{15}$ The council is part of the UAE's wider and ambitious project of exerting its political influence in the Muslim world through sponsorship of a diverse range of supra-national religious networks (Amasha 2020). This project arguably reached its pinnacle with the UAE's facilitation in Abu Dhabi of a meeting between the Pope and the head of Al-Azhar University, with the event being dramatically depicted as "a historic meeting between the two most prominent religious leaders in the world" (Amasha 2020). The third and final group of "international" influencers are independent scholars with a wide following in Western Muslim communities, with Muhammad Abul Huda Al-Yaqoubi representing a prominent example. Al-Yaqoubi was born and bred in Syria, undergoing his traditional Islamic studies there (Pulkkinen 2017). His relationship with the Western Muslim community began in 1991 when he enrolled in a doctoral program of linguistics at the Oriental Studies Department of the University of Gothenburg, eventually going on to becoming a researcher and professor of Arabic literature in Sweden (Qureshi 2012). The Swedish Islamic Society eventually appointed him the Mufti of Sweden, after which his influence slowly spread among Western Muslims, particularly after spending a year at Zaytuna College in the USA as a resident scholar under the patronage of Hamza Yusuf (Qureshi 2012). Al-Yaqoubi's influence is particularly pronounced in the UK, evidenced by his regular visits there and the number of British Islamic organizations listing him as their patron. ${ }^{16}$

Two organizations may be highlighted as prominent examples of high-profile "regional" players who exerted influence on the COVID-19 religious discourse in the UK. The first is SeekersGuidance, an online Islamic educational portal that has risen to become one of the most popular such Islamic educational hubs in the Internet market with over 3000 students per term taking part in a growing catalog of over 100 courses, and 100,000 students subscribed to their weekly newsletter. ${ }^{17}$ A distinctive characteristic of SeekersGuidance is its global reach across the network of Western Muslim communities, which is aided by both its diverse range of teachers who hail from a variegated collection of countries and educational traditions, and its nonprofit commitment with all of its courses being provided free of charge. ${ }^{18}$ The second organization is Darul Qasim, a progressive academic institute of Islamic learning based in Chicago with Deobandi affiliations. It is headed by Mohammed Amin Kholwadia, described by the organization as an expert

\footnotetext{
4 See (O'Sullivan 2001).

5 See (UAE Council for Fatwa 2020).

See for example (Guidance Hub 2020; Essential Islam 2019; Sacred Knowledge 2020).

7 See (SeekersGuidance 2020a).

8 See (SeekersGuidance 2020b).
} 
theologian whose "deep knowledge in the Islamic tradition and his aggressive engagement with contemporary issues facing everyday Muslims in the West has endeared him to young Islamic scholars and professionals all over." ${ }^{19}$ Kholwadia's influence over the Deobandi community in the UK is evident, with Wifaqul Ulama, for example, being one of the Britishbased organizations that share his media content on their personal media platforms. ${ }^{20}$ As would be expected, it was Kholwadia who issued an official verdict regarding COVID-19 on behalf of Darul Qasim, as shall be explored in the next section.

\section{COVID-19 vs. Theology: The Overarching Intellectual Paradigms}

The British Muslim response to COVID-19 and the closure of mosques marked a monumental engagement between public policy and theology, which could also be characterized at a deeper level as a prodigious engagement between tradition and modernity. Before delving into the web of specific responses, it is therefore helpful to sketch the broader contours and identify the key overarching intellectual paradigms which shaped and molded this engagement.

\subsection{The Spirit of the Law}

The first of these important intellectual paradigms which featured saliently in the COVID-19 discourses is the higher objectives of Islamic law, which is often characterized using the original term from classical Arabic, Maqasid Al-Shariah. Islamic law's primary scriptural sources, the Quran and Sunnah, express that the laws of the Shariah are the perfect manifestations of the fundamental moral principles also established in the texts (Waliullāh Al-Dihlawi 2005). In this sense, they are not ends unto themselves, but rather are means for a higher set of objectives. The science of Maqașid Al-Shariah, as developed by Muslim jurists, specifically deals with the body of moral principles that the laws of the Islamic legal system have been made to fulfill (Kamali 1999). These principles are thus seen by Muslim scholars as to the higher aims or purposes of the law, which together form its spirit. These include religious morals such as Taqwa or God-consciousness, as well as morals related more closely to the worldly dealings of man, such as absolute justice.

English legal scholars in the Common Law's heyday also had a keen sense of a spirit which "cut beneath the hard, dull surface of the law" (Winfield 1928). Their views are perhaps most famously represented by the 16th-century judge Coke, who stated, "Reason is the life of the law, nay the common law itself is nothing else, but reason; which is to be understood of an artificial perfection of reason, gotten by long study, observation and experience, and not every man's natural reason" (Coke 1832). Plowden also famously stated in this regard, "It is not the words of the law but the internal sense of it that makes the law, and our law (like all others) consists of two parts, viz. of Body and Soul; the letter of the law is the body of the law, and the sense and reason of the law is the soul of the law". ${ }^{21}$ Such jurists lived in a medieval era when religious scripture and some notion of natural law were factors that still played legitimate roles in the English legal process. Such a line of thought was therefore not dismissed as being farfetched until religion and all notions of natural law were wrenched out of the legal process in later centuries.

One of the most important fundamental aims of the Shariah is that it seeks to secure the welfare of people by promoting their benefit and by protecting them from harm. In this regard, the 13th-century Damascene scholar Ibn Taymiyyah states that "the purpose of the Shariah is to realize public welfare in totality and to prevent public harm as much as possible" (Ibn Taymiyyah 2004), and the 14th-century Spanish scholar Abu Ishaq al-Shatibi adds that "The Shariah was only established to benefit the slaves of God at all times" (Al-Shatibi 1997). In order to illustrate the Shariah's concern with the public welfare, Muslim scholars have divided the benefits which the Shariah aims for in its legal provisions

19 See (Darul Qasim 2020a).

20 See (Wifaqul Ulama 2020c).

21 Eyston v Studd [1573] 75 ER 688, 695 per Edmund Plowden. 
into three main categories: the Daruriyyat or "essentials", the Hajiyyat or "complementary," and the Tahsiniyyat or "embellishments" (Kamali 1999). The "essential" benefits are those on which the lives of the people depend for stability and whose neglect leads to total disruption and chaos. They consist of the five essential human values famously expressed by the 11th-century scholar Al-Ghazali, namely religion, life, intellect, lineage and property (Al-Ghazall 1937). The legal provisions of the Sharīah aim not only to promote but also to protect these values in order to secure the general welfare of the human being. Thus, for example, legal provisions relating to the ritual acts of worship like prayer, fasting, charitable alms and pilgrimage all secure the value of religion, while the legal provisions relating to physical needs such as eating, drinking and clothing all protect the value of life and intellect (Al-Shatibi 1997). Significantly, it was the two essential human values of faith and life that came into sharp conflict in the COVID-19 crisis, and the extent to which each value was considered and prioritized ultimately shaped the discourse of the religious actors grappling with the difficult dilemma of whether to keep places of worship open to the community during such a pandemic.

It is interesting to note a parallel between the five essential values of the law famously expounded by Al-Ghazali and a similar set of values most recently expounded by John Finnis. In his seminal work "Natural Law and Natural Rights", Finnis set about expounding certain fundamental values that serve the true purpose of the English common law (and any other legal system). He believes that an understanding of the purpose of the law is crucial to any study of the law or interaction with the law (Finnis 2011). Such an attitude and approach to the law is in complete synchrony with the Islamic legal tradition. The jurists of Islam have always paid great attention to the higher purposes or Maqasid of the Shariah because such higher purposes were expressed in the divine texts and explicitly connected with the laws. What is also interesting is the agreement between Finnis and Al-Ghazali on the specific set of fundamental values of the Law. Finnis stated that Life, Knowledge, Play, esthetic experience, sociability, practical reasonableness and religion were, in his opinion, the seven fundamental values that human beings need to flourish, and which the law should strive to protect (Finnis 2011). The five essential values expressed by Al-Ghazali and recognized by Islamic scholars also include life and religion. As for the others, such as intellect and family or lineage, they bear similar parallels with Finnis's principles of knowledge, practical reasonableness, sociability and life. ${ }^{22}$ The only Islamically recognized value which Finnis does not recognize is that of property, although he does still recognize it as an important concept which all societies recognize (Finnis 2011). Finally, both Finnis and Al-Ghazali accept that such fundamental values are universal, thus applying to all laws, whether man-made or divine (Al-Ghazall 1937; Finnis 2011).

\subsection{Legal Maxims}

The second important intellectual paradigm which also featured in and impacted the COVID-19 discourses is legal maxims. In the first four centuries of Islamic legal history, the main corpus of the Shariah's positive law was derived by Muslim jurists from the Quran and Sunnah through the process of expert legal reasoning, otherwise known in Islamic legal terminology as Ijtihad. This huge mass of legal rulings was eventually codified in the legal manuals of the four orthodox schools of law. After the first four centuries, jurists predominantly busied themselves with refining this body of positive law, only adding their own legal rulings on the few novel issues which arose thereafter. Towards the end of these first few centuries, Muslim jurists began a general survey of the entire corpus of the Shariah's positive law in order to derive common legal maxims (Abu Zahrah 1958). These took the form of concise rules and principles derived from the detailed legal rulings in the various legal manuals, which would help the jurist in deriving new legal rulings and adjudicating between people (Al-Suyuti 1997).

22 Finnis suggests including the transmission of life through procreation of children within his first value, that of Life. He has now also added the institution of marriage within the first value in a postscript in the second edition of his work (Finnis 2011). 
These maxims, however, only had a persuasive influence on the judge and jurist in the process of adjudication and legal interpretation and could never have a binding effect (Kamali 2008). Interestingly, the actual wording of these maxims was usually based on a verse of the Quran or a prophetic saying recorded in the Sunnah. The celebrated 15th-century medieval Al-Suyuti begins his work on legal maxims with the five maxims which Muslim jurists considered the most comprehensive of all, to the extent that they encompass together the essence of the Shari'ah. All other legal maxims are seen simply as extensions of these fundamental maxims (Al-Suyuti 1997). One of these five maxims was directly pertinent to the COVID-19 discourses in the UK, namely that "Harm must be removed." This is also expressed in the legal maxim literature from a communitarian perspective as "the removal of public harms takes priority over the obtainment of public benefits", which highlights Islamic law's fundamental concern in preserving the wellbeing of a community (Kamali 2008).

The English Common Law shares a very similar narrative to Islamic law with regards to legal maxims. It adopted the concept and even some maxims themselves from Roman Law. At an early point in their history, Roman jurists decided to organize their corpus of law along Aristotelian lines by unifying the common elements of experience into principles, which were then formulated as maxims. These maxims resultantly became an extremely authoritative source of law (Stein 1966). In a classical text on the legal maxims of the English Common Law, Francis Bacon observes that maxims can make the uncertainty of the law "more settle and corrected", as well as helping the soundness of judgments, gracing legal arguments and reclaiming vulgar errors (Bacon 1636). In another classical text of a similar nature, Broom also acknowledges the importance and authority of legal maxims in the English Common Law:

In the Legal Science, perhaps more frequently than in any other, reference must be made to first principles. Indeed, a very limited acquaintance with the earlier Reports will show the importance which was attached to the acknowledged Maxims of the Law in periods when civilization and refinement had made comparatively little progress. In the ruder ages, without doubt, the great majority of questions respecting the rights, remedies and liabilities of private individuals were determined by an immediate reference to such Maxims, many of which obtained in the Roman Law, and are so manifestly founded in reason, public convenience and necessity, as to find a place in the code of every civilized nation. (Broom 1874)

Broom very interestingly mirrors Suyuti by beginning with maxims which he believes "are of such universal application and result so directly and manifestly from motives of public policy or simple principles on which our social relations depend, that it has been thought better to place them first in this collection" (Broom 1874). Moreover some of the maxims cited in Broom's work can be found in Muslim works on legal maxims in almost identical form. A maxim cited by Broom states "a private mischief shall be endured, rather than a public inconvenience" (Broom 1874). The very same maxim may be found in the books of medieval Muslim jurists dealing with legal maxims, stating that "Harm to an individual is tolerated in order to prevent a harm to the public" (Kamali 2008). This maxim also epitomized Islamic law's communitarian philosophy and was acutely relevant to the COVID-19 dialog within the British Muslim community. Should the individual right to religious worship in mosques be superseded by the community's right to protection from a contagious disease whose spread is exacerbated by social group-interactions? Or is this potential harm to the community too negligible and hypothetical to override a sacrosanct individual right to prayer in the houses of God? These were the very real and difficult questions British Muslim religious leaders were initially faced with answering when the COVID-19 crisis unfolded. 


\subsection{Navigating Scripture: Legal Interpretation and Reconciling Conflicting Evidence}

The third and final intellectual paradigm, which shaped the COVID-19 religious discourse in the UK, was the navigation of scripture and legal interpretation. This proved to be a key cause of divergence in the responses of British Muslim leaders to the pandemic. Since medieval Muslim jurists emphasized the permanent and fixed status of the Quran and Sunnah as divine scripture, an accusation often leveled at Islamic law is that it is archaic and rigid and cannot deal with developments of society (Forte 1978). This assertion would certainly be correct if the legal provisions of the Quran and Sunnah were taken as the sole provisions that form the Islamic legal system as a whole. This is because the legal provisions in the Quran and Sunnah do not deal with every single detail of life. On the contrary, in many areas, they only provide the main details, leaving much scope for further legislation to be derived (Kamali 1991). In the famous epistle of the celebrated 8th-century medieval jurist, Al-Shafi'i-considered on one of the first classical works written on the philosophy of Islamic law-expert legal reasoning (or Ijtihad) is mentioned as the tool which was prescribed by the Quran to extend rulings from the two divine sources of the Islamic to those issues which they do not explicitly mention (Al-Shafi'i 1940). Legal interpretation dispensed by Muslim jurists is thus an indispensable tool of Islamic law, which gives it flexibility despite the permanent and fixed status of its two primary sources and enables it to be extended to the changing conditions of a Muslim community at any point in time.

Expert legal reasoning does not only involve the Muslim jurist deriving new rulings from the Quran and Sunnah on those issues which are not explicitly provided for in scriptural texts. It also involves interpreting the exact meanings of the provisions which are explicitly provided in those texts and determining the intention of the lawgiver (Al-Ghazall 1937). Muslim jurists acknowledge that while God's law is perfect, and his intention is clear, his law had to be transmitted through an imperfect medium, namely human language (Abu Zahrah 1958). Thus, his law is in need of interpretation, and it is not always clear what the intention of the lawgiver is from the language. In this regard, Muslim jurists involve themselves in a similar exercise to that of English judges who must interpret statutes and try to determine the intention of the draftsman. Both Muslim and English jurists have developed extremely intricate and detailed rules of interpretation to aid them in correctly determining the precise meanings and scope of the provisions of their respective laws, which they codified in books of legal philosophy (Kamali 1991). A natural consequence of this is that both Muslim and English jurists will differ in their legal opinions on an identical case due to differing methodologies in legal interpretation. This is particularly the case where there is a conflict of evidence, as was observed in the relevant scriptural texts related to the COVID-19 pandemic. Should British Muslim religious leaders consider the specific scriptural texts on health pandemics that require Muslims to take the necessary health precautions? Or should they instead focus on the plethora of scriptural guidance highlighting the importance of maintaining rituals of worship in all circumstances, even when one's life is at stake?

The dilemmas facing Muslim religious leaders when navigating scripture does not only stem from methodological differences in legal interpretation. It also extends to reconciling between scripture and modernity and requires an attempt to critically analyze and understand the realities of modernity to ensure a holistic application of scripture that remains loyal to its spirit. Al-Yaqoubi, a religious leader who engaged in the COVID-19 discourse, addresses the Muslim jurist's role of reconciling between scripture and modernity in a work he has published on Islamic pedagogy (Al-Yaqoubi 2016). He highlights two extremes that have historically existed among Muslims. The first are those jurists who master the intricacies of scripture but make no attempt to engage with modernity, choosing instead to isolate themselves and remain insulated from the vicissitudes of time. The second are scholars who dedicate themselves wholeheartedly to a critical engagement with modernity but who lack intimate knowledge of scriptural tradition. Al-Yaqoubi criticizes both camps and opines that the best jurist is one who combines mastery of scripture and a sincere attempt to engage with modernity (Al-Yaqoubi 2016). The mammoth challenge in 
this regard facing British Muslim religious leaders was fathoming as precisely as possible the full extent of COVID-19 s implications as a global health pandemic in the 21st-century, including the medical, social, political and economic considerations at stake.

\section{COVID-19 vs. Theology: The Arguments Advanced}

Having surveyed and critically assessed the key overarching intellectual paradigms that formed the theoretical framework underpinning British Muslim religious leaders' responses to COVID-19, it is now pertinent to explore the responses themselves. The analysis in this regard will be classified according to the two categories of key actors expounded above, namely the "activists" and the "academics". It should be noted that the responses generally emerged in the middle of March 2020, which marked the first month in which UK public policy began to seriously engage with the implications of an impending pandemic. The month began with a COBRA meeting held by the government to discuss its preparations for and method of engagement with the pandemic, as the number of UK cases jumped to $36 .{ }^{23}$ Public policy developments then moved at a fast pace, ultimately culminating in a televised address by Boris Johnson on 23rd March announcing a nationwide strict lockdown, which significantly included the closure of places of worship. ${ }^{24}$ At the time the responses emerged, the British Muslim community was therefore dealing with a real dilemma of whether to keep their mosques open at a time when it still remained legally permitted to do so, and future public policy developments remained uncertain. Once the lockdown was announced, however, all such discussions became academic as mosques were forced to close regardless of their personal convictions.

\subsection{Arguments of the "Activists"}

The British Islamic Medical Association (BIMA) and the Muslim Council Britain (MCB) both released official responses to the crisis on 16th March. This was the same day in which Prime Minister Boris Johnson had advised everyone in the UK against "non-essential" travel and contact with others, and The Department for Digital, Culture, Media and Sport advised that large gatherings should not take place. ${ }^{25}$

\subsubsection{The British Islamic Medical Association}

BIMA presented its response as an open letter to the Muslim community. It prefaced the letter by expressing its concerns that the response of the community to the crisis was at odds with what the seriousness of the pandemic demanded. ${ }^{26}$ The open letter was therefore intended to highlight "the clinical urgency and seriousness of the situation, on the continuation of congregational activities in Muslim institutions." 27 The term "Muslim institutions" in this context refers, of course, primarily to mosques, as the body of the letter itself makes clear. The fact that the letter focuses squarely on the issue of congregational activities in places of worship highlights significantly that this was at the epicenter of the discourse that emerged.

The letter began by highlighting that it was drafted by and represented "frontline Muslim health professionals". ${ }^{28}$ This intentionally chosen way of beginning establishes the basis of BIMA's authority to render an opinion on the pandemic and highlights the distinct nature and role of BIMA's influence and leadership in the community. Due to its medical expertise and intimate engagement with the British health system, BIMA's authority in public health events such as a pandemic enjoys special and distinguished status. The letter then proceeded by citing the warnings of the Prime Minister and the Chief

23 See (BBC News 2020a).

4 See (BBC News 2020b).

5 See (BBC News 2020c).

26 See (British Islamic Medical Association 2020b).

7 (British Islamic Medical Association 2020b).

28 See (British Islamic Medical Association 2020b). 
Scientific Advisor to avoid social interactions, before opining that the UK is on a similar trajectory to that of Italy, thereby justifying fears that the impact in the UK could be similar or worse than that in Italy. It then gave a concise overview of the medical implications for those who contract the virus, distinguishing between different groups of patients in this regard. While beneficial, this medical guidance would be expected from any medical organization regardless of religious (or other) affiliations. What was particularly beneficial and praiseworthy in the letter was the subsequent sociological analysis of the distinct demographic characteristics found within the Muslim community, which were relevant in relation to the particular impact that the pandemic would have on the community.

BIMA noted in this regard that the Muslim community has characterizes which place it at a higher risk than the general population, including an increased rate of chronic illnesses such as Diabetes, a significant elderly community and regular communal gatherings for both social and religious purposes. ${ }^{29}$ It also noted other sociological phenomena in the Muslim community which post distinct risk factors for spreading the virus, including densely populated households that lack adequate ventilation, social habits which involve physical interactions such as handshaking, physical contact with carpets during ritual worship and the sharing of washing facilities also for the purpose of ritual worship. Based on this outline, BIMA warned that congregational activities in mosques could significantly exacerbate the spread of the virus, adding that individuals may contract the virus without showing any symptoms for up to two weeks. The advice being given by some mosques and religious leaders that only those at risk should stay away from the mosque was thus not adequate, as seemingly healthy individuals could end up transmitting the virus to members of their household. The community was also warned that the NHS was in danger of being overburdened, which could further put lives in danger, as was being witnessed in Italy, where many patients looking for treatment had to be turned away.

BIMA's combination of analyzing the distinct demographics of the Muslim community alongside both its medical expertise and intimate relationship with the NHS in order to provide such precise and tailored advice is highly praiseworthy, particularly since it challenged the standard advice being given at the time by a number of mosques and religious leaders. ${ }^{30}$ This highlights the marked value of BIMA's leadership and authority within the British Muslim community in a health crisis and more broadly epitomizes the importance of religious leadership, which combines professional expertise and intimate knowledge of relevant sociological factors related to a socio-political event. BIMA ended the letter by emphasizing its view that mosques should not remain open even with significant adjustments in place for the reasons it had outlined. The first sign of its religious affiliation also appeared towards the very end of the letter, with BIMA describing God as "the disposer of all our affairs, the protector of us all." ${ }^{31}$ It also crucially recognized its lack of theological qualifications to issue a religious verdict on the matter and framed its response as a strictly medical and professional perspective, stating "we recognize this is a decision for scholars, imams and mosques committees to make and we urge them to take steps to mitigate harms." ${ }^{\prime 2}$ This is also a praiseworthy approach, with BIMA not only recognizing the limits of its professional authority but also embracing a cooperative and communitarian spirit by respecting the role of the community's religious leaders in contributing to the discourse.

\subsubsection{The Muslim Council of Britain}

The MCB's response was much briefer and less detailed than BIMA's response, something which is expected given the MCB's lack of professional, grassroots or religious expertise on the matter. It began with a much more forthright call for all mosques and

29 See (British Islamic Medical Association 2020b).

30 See (5pillars 2020b).

31 See (British Islamic Medical Association 2020b).

32 See (British Islamic Medical Association 2020b). 
religious centers to suspend congregational activities. ${ }^{33}$ It acknowledged the important sociological role of the mosque within the community as well as the religious importance of the congregational prayer, noting that its advice to suspend all congregational activities "had not been taken lightly." ${ }^{34}$ It then clarified the different basis for issuing such guidance. In terms of medical expertise, it cited both the view of the UK's chief scientific advisors and the letter issued by BIMA. To enhance the legitimacy of BIMA's view, it highlighted that BIMA represents "Muslim medical and health professionals, who bring together a knowledge of communities as well as medical expertise." ${ }^{\prime 35}$ The MCB then turned to the religious basis for its advice, citing the view of the British Board of Scholars and Imams (BBSI) that the religious obligation on members of the Muslim community to perform congregational prayer had been temporarily uplifted.

The MCB rounded off its guidance with a statement from its secretary-general Harun Khan. After emphasizing the "public duty" of protecting communities from harm, which was backed by both "medical and scholarly advice", Khan turned attention to altruistic social opportunities that the pandemic presented and urged British communities to "come together and support one another". ${ }^{36}$ Overall, the MCB's response typifies its role as an activist umbrella organization. Due to its vast networks, it was easily able to rely on BIMA's expert medical advice, with BIMA being one of its own members. Its reliance on BBSI for religious legitimacy, however, was more controversial. BBSI's religious verdict was one of several verdicts issued by religious institutions within the Muslim community and by no means represented the view of all religious leaders, as shall be explored in the forthcoming analysis. This illustrates the challenges that an umbrella organization like the MCB faces in such circumstances, as it is forced to make difficult choices while arguably lacking the adequate qualifications to do so. Moreover, its activist impulses and intimate engagement in the political process means that it can readily be characterized in such a situation with a bias towards prioritizing public policy over theological considerations. This leads aptly onto the response of the Islamic Human Rights Commission, where these shortcomings were more vividly manifested.

\subsubsection{The Islamic Human Rights Commission}

The Islamic Human Rights Commission (IHRC) released an article on 20th March written by Faisal Bodi, a member of the IHRC who is vaguely described as a "writer and political commentator" with no more information forthcoming about his biography or qualifications. ${ }^{37}$ Bodi began by noting the polarization of opinion among the Muslim community between the two conflicting positions of closing mosques completely and keeping them open with relevant precautions in place, which included limiting the congregational prayer to a small number of chosen individuals from the lower-risk cohorts. ${ }^{38}$ He then noted that a number of mosques had already closed in line with both government advice as well as the advice of the Muslim Council of Britain and the British Board of Imams and Scholars, which had both also emphasized full precautions be taken in order to reduce the transmission of the disease. Bodi then went on to fiercely criticize two positions taken by mosques and religious leaders who aligned themselves to the other side of the spectrum.

The first was the advice given to the community to perform congregational prayers at home with neighbors and friends in order to make up for the lost opportunity to do so in the mosque. Bodi described this approach as "self-defeating" due to the fact that the reasons for closing down mosques also apply in the same way to avoiding congregational

\footnotetext{
See (MCB 2020).

See (MCB 2020).

See (MCB 2020).

See (MCB 2020).

See (The Islamic Human Rights Commission 2020b).

See (The Islamic Human Rights Commission 2020c).
} 
activities in community homes. ${ }^{39}$ He then went on to justify his position theologically by stating that "almost all of the Sunni and Shia schools" of Islamic law do not consider congregational prayer to be obligatory, but rather only recommended. ${ }^{40} \mathrm{He}$ continued by claiming that despite the Sunni Shafi'i school of law considering it to be obligatory, it still considers the obligation, in general, to be fulfilled if a chosen group of individuals fulfill it. This analysis is problematic from a number of perspectives. The first is that Bodi, who is presented by the IHRC as a political commentator, lacks the theological qualifications to make authoritative references to Islamic law. This shortcoming is vindicated by the shortcomings in his argumentation. The first is that the position of Shafi'i school of law is more nuanced than he presents. A legitimate opinion in the Shafi'i school opined by the celebrated medieval jurist Al-Rafi'i is that the daily congregational prayer is not obligatory (Furber 2013). This opinion sits alongside the admittedly more relied upon the opinion of the Shafi'i school's most prominent medieval jurist Al-Nawawi, who disagreed and opined instead that it is communally obligatory (Keller 1997, 2003; Furber 2016). More important, Al-Nawawi's opinion considers the congregational prayer one of the public symbols of Islamic society and therefore considers congregational prayers being performed entirely at home as insufficient to fulfill the obligation. The medieval jurist Umar Barakat states in this regard: "In a city, the prayer must be held in public places such that the manifestations of obedience to Allah's command are evident. If held in houses where the rite of prayer is not public, the obligation remains unfulfilled" (Keller 1997). Furthermore, a much more important omission was the view of the Sunni Hanafi school, which is the most-followed school of law within the British Muslim community and whose position should have, therefore, at a minimum, been highlighted (Mohammad 2013). As with the Shafi'i school, some jurists in the Hanafi school not only considered the congregational prayer in the mosque to be obligatory but also one of the major symbols of Islam (Ibn Abidin 1994; Al-Kasani 1986; Burhanpuri 1991). This explains why many mosques were so adamant about keeping their doors open in order to preserve such a symbolically important religious ritual. The Sunni Hanbali school's view was also overlooked, in which congregational prayer is considered personally obligatory, albeit allowing for it to be done at home with its performance in the mosque merely recommended (Al-Buhuti 2002). Bodi's analysis thus reveals a similar bias towards a public policy that stems from his political background, epitomized by his statement during his criticism that "our community is approaching the issue from the wrong angle. Instead of asking the question: "What can we do to help contain the Covid-19 pandemic?" they are asking, "What can we do to maintain congregational prayer?". 41

Bodi then went on sharply criticizing "the more disturbing" position of mosques that had kept their doors open and insisted that sanitary precautions within the mosque would be sufficient, describing this as "the height of irresponsibility". ${ }^{42} \mathrm{He}$ once again provided a number of theological arguments against this position, stating that there were historical precedents in the Muslim world of mosques closing down in pandemics and that several countries, including Morocco and Saudi Arabia, had taken the decision to suspend congregational prayers. No references were given, however, either for the historical precedent of mosque closure or for the theological arguments which formed the basis for the position of the Muslim countries mentioned. Bodi ended the article by making a further theological argument that religiosity should not be seen as a manifestation which is limited to the mosque, and also echoed the MCB's call to take advantage of the altruistic social opportunities presented by the pandemic, stating, "Let us reach out into our neighborhoods and social circles to help those who are adversely affected by

39 See (The Islamic Human Rights Commission 2020c).

40 See (The Islamic Human Rights Commission 2020c).

41 See (The Islamic Human Rights Commission 2020c).

42 See (The Islamic Human Rights Commission 2020c). 
the new circumstances." ${ }^{43}$ Bodi's arguments were also bolstered by a statement from the IHRC's chairman Massoud Shadjareh who castigated the Muslim community for a "failure of leadership" and advanced arguments to support the suspension of congregational activities in mosques similar in style to the ones presented by Bodi. ${ }^{44}$

While the IHRC's guidance on mosque closure can be criticized for lacking both nuance and scholarship, their role in critiquing media coverage of the British Muslim community's response to COVID highlighted their potential leadership value as a Human Rights NGO with political expertise. On 7th August 2020, the chairman of IHRC Shadjareh sent a letter of complaint to the Director-General of the $\mathrm{BBC}$ regarding their coverage of the Muslim community's engagement with the COVID-19 crisis. ${ }^{45}$ Shadjerah highlighted a number of BBC articles reporting on the worrying spread of the pandemic, which fielded photographs of Muslims in particular, which Shadjerah claimed was exacerbating negative stereotypes about the Muslim community. The letter also sharply pinpointed a discrepancy between a BBC article on 19th July negatively reporting that a Blackburn mosque faced a police investigation for having over 250 individuals attending a funeral, and another article two days later which positively reported footballer Jack Charlton's funeral despite the fact that the funeral was attended by thousands of his supporters. This critique is all the more pertinent when taking into account the phenomenon of Islamophobia, which has become a major concern among British Muslims due to its exponentially increasing rate in public and media discourses (Githens-Mazer and Lambert 2010; Sayyid 2014; Elahi and Khan 2017).

\subsection{Arguments of the "Academics"}

While the "activists" were united in calling for a swift suspension of congregational activities in mosques, the "academics" fell into two opposing camps. Each camp wielded its own detailed theological arguments to advance its position and exert its authority on its dedicated set followers, which included both mosques and individual members of the community. The forthcoming analysis will therefore classify the responses into two categories, namely those who supported the closure of mosques and those who insisted mosques should remain open albeit with certain qualifications.

\subsubsection{Proponents of Mosque Closure}

One of the most comprehensive, detailed and well-presented responses from the camp supporting mosque closure, spanning 15 pages in total, was that issued by the British Board of Imams and Scholars (BBSI) and aptly titled "UK Community Briefing paper for Imams, Mosques, and Madrasas for the coronavirus Pandemic" (BBSI 2020c). It was thus impressive that this guidance was issued so swiftly on 16th March 2020, the same day in which the Muslim Council of Britain and the British Islamic Medical Association both issued much shorter and less detailed statements. The briefing paper was officially presented as a collaboration between BBSI and both Wifaqul Ulama and the Mosques and Imams National Advisory Board (MINAB), with the paper closing its executive summary by stating: "In collaboration with Wifaqul Ulama and MINAB, we are issuing holistic guidance on community resilience with regards to the coronavirus pandemic, based on the spread of opinion within this ecumenical fellowship of scholars" (BBSI 2020c). The inclusion of both organizations as partners to guidance is significant in different ways. Wifaqul Ulama's inclusion was significant due to the fact that Wifaqul Ulama adopted its own independent position, which initially inclined against mosque closure, but also because of Wifaqul Ulama's dedicated Deobandi affiliation, which stands in stark contrast to the ecumenical ethos of BBSI. This, therefore, illustrates BBSI's conciliatory and all-inclusive approach, which is further manifested within its guidance by its expression of respect towards the views of the opposing camp. MINAB's inclusion

43 See (The Islamic Human Rights Commission 2020c).

44 See (5pillars 2020c).

45 See (The Islamic Human Rights Commission 2020d). 
was also significant due to its particular influence over UK mosques as an umbrella body, mirroring a similar influence enjoyed by the Muslim Council of Britain. Formed in 2006 in collaboration with the Muslim Council of Britain as well as other organizations, it now enjoys over 600 mosques and Islamic Centers as members (Rahman et al. 2010).

The BBSI structured its briefing paper into nine sections, key among which was a section on the principles underpinning the guidance, a section highlighting a spiritual perspective on the pandemic, two sections detailing the theological and legal arguments justifying BBSI's position on mosque closure, and finally two sections covering the broader ethical duties and responsibilities of the community in relation to the pandemic. The paper was also prefaced with an executive summary summarizing its key points. This sophisticated structure alongside the esthetic enhancements which the paper enjoyed distinguished it from the responses of other organizations such as Wifaqul Ulama and Islam21c, which perhaps reflects the contribution of the university academics who are members of the Board, but also more broadly the progressive academic capacities of the Board's diverse range of members. BBSI began in its first section by briefly noting the medical reasons which render the pandemic a dangerous public health risk, as well as the demographics of the Muslim community, which could exacerbate the risk posed by the virus to the community's vulnerable members. The paper did not delve into detail on these points, noting that they had been "clearly evidenced by medical experts worldwide and need not repeating here" (BBSI 2020c). No reference was made to the British Islamic Medical Association's guidance letter, perhaps because it had been released on the same day that the paper was also issued.

The following section, which outlines the principles underpinning the guidance, is useful in illustrating BBSI's approach and methodology in engaging with public policy and projecting their religious authority over the Muslim community. The section emphasized that the guidance was based on a tripartite set of scriptural, jurisprudential and empirical sources. This portrays a methodological insistence on combining a scholarly understanding of both tradition and modernity and eschews stereotypical dichotomies such as the dichotomy between religion and science or scriptural and empirical evidence. This methodological approach, which considers both spiritual and material considerations, is further emphasized by the BBSI in the same section where it states: "We take our responsibility seriously to minister to the welfare of the community-both worldly and next-worldly" (BBSI 2020c). This approach is manifested in the BBSI's particular perspective on the higher purposes of Islamic law, otherwise known as Maqasid Al-Shariah, which is also indicated in this section. In this regard, the emphasis is laid on the "serious importance that our religion places on life, health, community, and spiritual wellbeing... As our scholarly tradition demands, our approach in the guidance is directed by consideration of what is essential, recommended, and desirable" (BBSI 2020c). A final important feature of the section on the principles underpinning the guidance was the affirmation that public policy takes precedence over any of the instructions in the guidance, such that if government directives were issued overriding the guidance, then "the government directives would take priority" (BBSI 2020c). This reflects an orthodox theological standpoint in relation to Muslims engaging with public policy, which considers adherence to the law of the land a religious obligation. This orthodox standpoint is succinctly outlined by Darul Qasim (classified in the preceding analysis as a regional influencer) in the following way:

... in line with the rulings of authoritative Muslim jurists of the past and present, Muslims must abide by the laws of the sovereign state in which they reside. Following the law of the land is incumbent upon Muslims wherever they may choose to live. Any protest and/or demonstration against policies of the state must be within the legal boundaries of the given state and its laws. Anyone who 
chooses to violate the laws of the land should not use religion (i.e., Islam) as a cloak to violate its rules and regulations. ${ }^{46}$

Understandably, this theological standpoint featured prominently in the responses of those who supported mosque closure, as can clearly be seen, for example, in the response of the UAE Fatwa Council. ${ }^{47}$

The sections of the guidance offering a spiritual perspective on the pandemic and covering the broader ethical duties and responsibilities of the community in relation to the pandemic highlight the comprehensive and holistic nature of the guidance. In the section offering a spiritual perspective, the BBSI stressed that the community's response to the pandemic should be "informed by a transcendent theological and spiritual outlook" which involves having firm conviction first and foremost that "benefit and harm comes from God, and that all proceeds exactly in accordance with his pre-eternal Decree" (BBSI 2020c). The community was reminded that calamities are an inevitable part of this earthly life which give the opportunity to "deepening our connection with the Divine, supporting one another towards patient endurance and ultimate truth, and thankfulness for the many blessings that often go unremembered" (BBSI 2020c). The ethical duties of the community on such an occasion were also stressed, with the guidance calling on the community to "being a mercy to creation, and loving for each other in humanity what we would love for ourselves" (BBSI 2020c). This spiritual perspective complimented the subsequent legal guidance, blending jurisprudence with ethics in a combination which is typical of religious guidance and which often distinguishes it from guidance issued by secular legal bodies. The infusion of spiritual guidance more broadly illustrates the multidimensional nature of the influence which clerical organizations such as the BBSI wield over the community, a trend which can, for example, also be found among Shariah tribunals such as the Muslim Arbitration Tribunal (Al-Astewani 2019).

The BBSI's promotion of mosque closure centered on two key legal rulings relating to congregational prayer in the mosque, namely the daily and Friday congregational prayer, respectively. Unlike other faiths, communal worship in Islamic law is congregational and not individual, and so the congregational prayer-which represents the central ritual of worship in mosques-became the epicenter of discussion among British Muslim religious leaders in the background of COVID-19. The BBSI began its legal analysis by noting the specific medical risks associated with mosques in the context of a pandemic, noting "the possibility of acquiring the virus from hard surfaces in the mosque, such as ablution areas, or from carpets during prostration..., the usage of water and presence of bodily fluids; and the difficulty of managing attendance" (BBSI 2020c). The BBSI went on to opine that the Muslim community should avoid congregational prayer in the mosque, citing a number of legal arguments to support its position. The first of these was the "majority opinion that identifies the performance of congregational prayer in the mosque as recommended, not obligatory" (BBSI 2020c). As previously analyzed in regards to a similar statement made by the Islamic Human Rights Commission, this statement fails to acknowledge the emphasis that both the Hanafi and Shafi'i schools of Islamic law place on the congregational prayer as one of the major public symbols in an Islamic community. This shortcoming was rectified in the responses of the opposing camp, as shall be seen. A list of legal maxims was then listed which emphasize that protecting the community from harm takes precedence over the acquiring of religious benefits, such as the legal maxim which states "Averting harm takes precedence over acquiring benefit" (BBSI 2020c). This list crucially included what was described as the "contagion principle", a reference to a scriptural text in Islamic law which specifically promotes social distancing and the taking of precautionary measures in a pandemic (BBSI 2020c).

With regard to the Friday congregational prayer, the BBSI acknowledged that calling for the suspension of the Friday prayer was a much more contentious and sensitive topic,

46 See (Darul Qasim 2020b).

47 See (UAE Council for Fatwa 2020). 
since this prayer is unanimously considered a legal obligation in Islamic law and "a clarion sign of Islam" (BBSI 2020c). Nevertheless, it affirmed that a majority of its members opined that the obligation of the Friday prayer should be "lifted from the generality of UK Muslims" (BBSI 2020c). In addition to the legal evidences already given regarding the daily congregational prayer, it was noted that Islamic law allowed for a number exemptions from the obligation to attend Friday prayer which were based on relative minor degrees of harm such as excessive rain or cold, and which specifically included the fear of illness. It was also noted that valid opinions do exist in Islamic law which allow the Friday prayer to be conducted outside of the mosque with a minimum of three congregants, which could offer an alternative to attending Friday prayer at the mosque. The legal analysis as a whole was situated within the context of the pandemic, with regular reference to the particular risks of COVID-19 within the Muslim community. Overall, the legal analysis was nuanced and represented a sincere attempt to combine between both scriptural and empirical realities, as well as taking into account the overall welfare of the community. It is perhaps because of this nuance, but also because of the BBSI's diverse and ecumenical range of members that its guidance enjoyed significant influence, being cited, for example, by the Muslim Council of Britain to support its own position.

This influence moreover transcended the Muslim community, with the guidance being significantly cited by an English judge in the High Court case of R (Hussain) v Secretary of State for Health and Social Care which was decided in June, a few months following the lockdown imposed by the government. ${ }^{48}$ The case involved a judicial review challenge by the Chair of the Jamiyat Tablighi-Ul Islam Mosque in Bradford against the government's closure of mosques, arguing that his consequent inability to perform the Friday prayer violated his Article 9 right to religious freedom. Justice Swift rejected the claimant's application, and supported his legal reasoning by making reference to a number of sections in the BBSI's briefing paper, including a large segment of the section dealing with the suspension of the Friday prayer. ${ }^{49}$ He highlighted the comment made by the BBSI in the beginning of its briefing paper that government directives should take precedence over any conflicting religious guidance, noting that this principle was "of note" because "this document was published before the 2020 Regulations were made and came into force." ${ }^{\prime 50} \mathrm{He}$ also noted that the claimant's own beliefs "differs from the majority view stated by the British Board of Scholars and Imams", but that "the overall fair balance can recognize the indisputable point that the Claimant's beliefs as to communal Friday prayer in current circumstances are not beliefs shared by all Muslims." ${ }^{\prime 51}$ This discourse represents an interesting interaction between the English judiciary and Islamic law, with the BBSI's guidance proving to be an effective medium which empowered and facilitated the ability of an English judge to navigate through the issues of a complex religious issue facing the Muslim community.

The influence of the BBSI's guidance was also amplified by support from abroad by both international and regional influencers. The UAE Fatwa Council issued a legal verdict on 3rd March promoting strict adherence to government directives regarding the pandemic, social distancing and the taking of maximum precautionary measures in relation to congregational prayers in the mosque. ${ }^{52}$ The verdict's detailed scriptural evidence was more expansive than the briefer scriptural references made in the BBSI's guidance, and included verses from the Quran prohibiting self-harm, prophetic teachings promoting social distancing during pandemics, and legal maxims such as "Risk of individual harm is endured in order to repel public harm." 53 The verdict also cited relevant historical

48 See (BAILII 2020).

9 See (BAILII 2020).

50 See (BAILII 2020)

51 See (BAILII 2020).

52 See (UAE Council for Fatwa 2020).

53 See (UAE Council for Fatwa 2020). 
precedents which supported its position, such as the decision by the prominent Muslim governor Amr Ibn Al-Aas in the 7th-century to direct the people of a city afflicted with a plague up into the mountains until the plague was lifted. SeekersGuidance also issued a number of articles via its online media platforms supporting social distancing and the suspension of congregational activities, including an article by a BBSI member who made reference to the BBSI's briefing paper. ${ }^{54}$ Another important historical precedent was also cited in one of these articles which presented a Shafi'i perspective on the pandemic. In the 16th-century, the prominent medieval Shafi'i jurist Shihab Al-Din Al-Ramli was asked about the suspension of Friday prayer in a locality swamped by torrential rain, to which he affirmed that the obligation of attending the Friday prayer would indeed be legally suspended in such a situation. Commenting on this, the author of the article stated: "Hence, the option that some countries have taken of temporarily suspending Jumu' ah and the daily congregational prayers is one that poses no problem in terms of the Shari'ah." 55 Finally, independent scholars from abroad also issued individual verdicts supporting the suspension of the Friday prayer obligation on the Muslim community. In a brief YouTube video specifically addressed to European Muslims for example, Mohammad Al-Yaqoubi opined that the legal maxim "preventing harm is prior to bringing benefit" was sufficient in providing an exemption for Muslims from attending the Friday prayer. ${ }^{56}$

\subsubsection{Opponents of Mosque Closure}

A foundational characteristic of the arguments advanced by proponents of mosque of closure was a certain approach to the higher purposes of Islamic law in which the value of life was prioritized over the value of religion. This prioritization was flipped in the opposite direction by opponents of mosque closure, who considered the value of religion to be more pressing. Both approaches affected the nature of the arguments which each camp advanced. Proponents of mosque closure, for example, focused on the scriptural evidences which consider protection from harm as a sacred duty, and were much more willing to take into consideration the dangerous risks the pandemic posed to the Muslim community. Opponents of mosque closure on the other hand focused on scriptural evidences which emphasize the sacrosanct nature of the congregational prayer, and were much less willing to subjugate themselves to the medical estimations of the potential risks which the pandemic posed.

While Wifaqul Ulama responded quickly to the pandemic by posting daily social media posts with updates on the situation, it was in fact another Deobandi-affiliated organization whose response was initially more popularly shared among the Muslim community. The Islamic Portal describes itself as an online "gateway to the Islamic sciences" whose objective is to "to empower Muslims with the knowledge and confidence to practice their faith and become beacons of guidance and change." 57 On 17th March a question was posed asking whether UK mosques should remain open or closed, with the questioner stating there was "a lot of confusion" within the community on this issue. ${ }^{58}$ The question was answered by Yusuf Shabbir, a graduate of the UK-based Deobandi seminary Dar AlUloom Bury. Shabbir acknowledged the severity of the pandemic and that such a decision could not be taking lightly, going on to opine uncompromisingly that mosques should remain open and only close if the government places a total restriction on places of worship. He clarified that only those diagnosed with COVID-19 or suffering from its symptoms should stay at home, as well as those with underlying health conditions. Everyone else should attend the mosque as usual, including over $60 \mathrm{~s}$ who are healthy. Shabbir then listed a succinct list of evidences for this position. With regard to the higher purposes of Islamic

\footnotetext{
54 See (SeekersGuidance 2020c, 2020d, 2020e).

55 See (SeekersGuidance 2020d).

56 See (YouTube 2020).

7 See (Islamic Portal 2020a).

58 See (Islamic Portal 2020b).
} 
law, it was categorically stated that "The protection of faith supersedes the protection of one's self." 59 The importance of mosques and the congregational prayer were then also highlighted, noting that the congregational prayer remained an obligation in Islamic law even during warfare, and that congregational prayer is a spiritual remedy which should be "part of the solution and not the problem." 60 As for scriptural texts promoting precaution during pandemics, it was claimed that these did not mention closing mosques and there was no historical precedent in Islamic history for mosque closure during pandemics. Finally, the "ground reality" of schools remaining open and Muslims continuing to attend social gatherings such as weddings and visit shopping centers rendered mosque closure an unjustified anomaly. ${ }^{61}$ For such reasons, Shabbir stated mosques should remain open with the appropriate precautionary measures in place applied in a proportionate manner. It was also noted that such an answer was given after consultation with "local Public Health England" officials who felt this was a reasonable and proportionate response. ${ }^{62}$

Wifaqul Ulama generally supported this position, with the qualification that over 60 s should stay at home. ${ }^{63}$ It also recommended practical precautionary measures such as doing the ablution for the prayer at home before going to the mosque, bringing a face towel to pray on in order to avoid contact with the carpet, and to stay away from the mosque if afflicted with COVID-19 symptoms. In an article featured on Islam21c's website, this position was also supported by Haitham Al-Haddad, who stated that "no one has a right whatsoever to close the Houses of God" and cited in this regard a verse from the Quran which states "Moreover, who are more unjust than those who prevent the name of Allah from being mentioned in His mosques and strive toward their destruction." 64 Al-Haddad then dealt with the hypothetical situation of a lockdown and mosque closure with regards to suspension of the Friday prayer. After listing a number of scriptural texts highlighting the sacrosanct status of the Friday prayer, Al-Haddad advised Muslims to continue to perform the Friday prayer in such a situation within small groups at home "or even at parks". 65 This particular directive marks a stark contrast to the insistence by proponents of mosque closure that government directives should be strictly adhered to and that maximum precautions should be taken. At a deeper level, it reflects a different theological approach to engaging with public authority, and conforms with Islam21c's engagement in political activism.

The position taken by opponents of mosque closure was bolstered by support from abroad. Darul Qasim took a similar position to Wifaqul Ulama, recommending against the outright suspension of Friday prayer until government authorities bar places of worship from congregational activities. It acknowledged Islamic law's imperative to avert harm, but highlighted the importance of maintaining "the emblems of faith as much as possible."66 Taqi Uthmani also pledged to keep mosques open along with a number of Pakistani religious leaders despite government directives that precautions should be taken. This led to tensions between the Pakistani government and the country's religious leaders which involved some clashes between security forces and mosque prayer leaders. ${ }^{67}$ Despite these influences from abroad however, opponents of mosque closure in the UK began to take a more conciliatory stance as time passed on, and the dangerous risks of the pandemic became more apparent. Islam21c, for example, posted a subsequent article by Dr. Sajid Umar, another prominent teacher who is regularly featured by the organization, which

\footnotetext{
See (Islamic Portal 2020b).

See (Islamic Portal 2020b).

See (Islamic Portal 2020b).

See (Islamic Portal 2020b).

See (5pillars 2020c).

See (Islam21c.com 2020b).

See (Islam21c.com 2020b).

See (Darul Qasim 2020c).

See (5pillars 2020d).
} 
highlighted the legitimacy of the arguments advanced by proponents of mosque closure. ${ }^{68}$ More significantly, over twenty Deobandi religious leaders gathered together on 21st March in Blackburn to discuss the ongoing crisis of the pandemic, with the gathering including both Yusuf Shabbir and members of Wifaqul Ulama. ${ }^{69}$ While maintaining that a full mosque closure should still be avoided, the scholarly summit agreed that the Muslim community could be exempt from attending both the daily and Friday congregational prayers due to the "urgent need to take further measures to stem the spread" of the "deadly virus". ${ }^{70}$ Two days later, the nation-wide lockdown announced by Boris John rendered all such discussions nugatory, as mosques were forced to closed and a legal challenge attempting to resist such a move ultimately failing.

\section{Closing Reflections}

Many general observations can be made from the preceding analysis about the nature of religious authority in the British Muslim community. The first is the sophisticated level at which this authority is now wielded by the community's religious leaders. The responses of the community to COVID-19 and mosque closure analyzed in this paper show how much religious leadership has matured and developed since Muslims first began establishing communal institutions in the second-half of the 20th-century after settling in the UK. The diverse spectrum of responses reflects the development of an equally diverse range of both activist and academic institutions with sophisticated organizational models that represent the community at regional and national levels and confidently engage with public policy. The maturity of these institutions was reflected in their level of coordination when engaging with COVID-19 public policy. The expert medical advice issued by the British Islamic Medical Association, for example, proved to be an indispensable reference point for other institutions involved in the discourse. The British Board of Imams and Scholars (BBSI) also coordinated with both Wifaqul Ulama and the Mosques and Imams National Advisory Board when issuing its religious guidance. This coordination is particularly note-worthy when taking into account the different and sometimes opposing theological affiliations of such institutions, indicating that in times of crisis, religious leaders in the Muslim community are willing to embrace an ecumenical ethos for the broader benefit of overall community welfare. Such coordination was also facilitated by what may be characterized as the "new Muslim media", namely newly formed organizations by British Muslims with media expertise that focus on analyzing current affairs in a format tailored towards the Muslim community. 5PillarsUK is a leading example of new Muslim media, currently enjoying over 300,000 followers on its Facebook page and managing an active website that broadcasts a diverse coverage of current affairs with a specific focus on the British context. ${ }^{71}$ 5PillarsUK played an instrumental role in covering the issue of COVID-19 and mosque closure and broadcasting the responses of key religious leaders within the community. A proof of the sophisticated overall response from the community was an English court's willing reliance on the guidance issued by the BBSI, which also represented a momentous interaction between Islamic law and the English legal system.

On the other hand, differences of opinion within the responses highlight the importance which theology plays in the manifestation of religious authority within the community. Different methodological approaches, for example, to the higher purposes of Islamic law, Islamic legal maxims, interpretation of scripture and engaging with state authority, resulted in opposing views on mosque closure, which consequently led to opposing policies adopted by mosques across the country, with some insisting on keeping open. The role of theology in such discourses also reflects the multidimensional nature of religious authority as it manifests in the Muslim community. The BBSI's holistic engagement with COVID-19

\footnotetext{
68 See (Islam21c.com 2020c).

69 See (Summary of the Coronavirus Ulama and Medical Professionals' Summit 2020).

70 See (Summary of the Coronavirus Ulama and Medical Professionals' Summit 2020).

71 See (5pillars 2020e).
} 
epitomizes this fact, with its guidance addressing the issue from spiritual, theological, social, legal and practical perspectives. In this sense, such religious authority can be directly contrasted with the legal authority of English law, which is often unidimensional as could be illustrated, for example, by the court case explored in the analysis, which dealt with a legal challenge to mosque closure.

Overall, the responses of the Muslim community to the COVID-19 crisis highlighted the dynamism within the community's social structures. This was further manifested in the community's adjustment to the lockdown imposed by the government towards the end of March, imposing a forced closure of mosques. Very quickly, mosques switched to the delivery of services using online platforms. ${ }^{72}$ There was also a burst of humanitarian initiatives to support those negatively affected by the pandemic, with examples including a mosque being converted into a hospice, the donation of a building worth five million pounds to the NHS, and a community initiative that offered free legal coverage of the lockdown's implications on daily life. ${ }^{73}$ The Muslim community thus proved it could deal effectively with a pandemic, boding well for future challenges which it no doubt will continue to face in a turbulent 21st-century world.

Funding: This research received no external funding.

Conflicts of Interest: The author declares no conflict of interest.

\section{References}

5Pillars. 2020a. Muslim Leaders Urge Government to Allow Congregational Prayers in Mosques. Available online: https:// 5pillarsuk.Com/2020/11/05/Muslim-Leaders-Urge-Government-To-Allow-Congregational-Prayers-In-Mosques/ (accessed on 18 December 2020).

5pillars. 2020b. Hundreds of UK Mosques Remain Open for Jumu'ah Despite Closure Calls. Available online: https://5pillarsuk.com/ 2020/03/20/hundreds-of-uk-mosques-remain-open-for-jumuah-despite-closure-calls/ (accessed on 18 December 2020).

5pillars. 2020c. IHRC Chairman: All Mosques Should Be Closed over Coronavirus. Available online: https://5pillarsuk.com/2020/03/ 15/ihrc-chairman-all-mosques-should-be-closed-over-coronavirus/ (accessed on 18 December 2020).

5pillars. 2020d. Pakistani Scholars Pledge to Open Mosques Despite Coronavirus Lockdown. Available online: https://5pillarsuk. com/2020/04/16/pakistani-scholars-pledge-to-open-mosques-despite-coronavirus-lockdown/ (accessed on 18 December 2020).

5pillars. 2020e. Homepage. Available online: https:/ /5pillarsuk.com/ (accessed on 18 December 2020).

Abu Zahrah, Mohammad. 1958. Usul Al-Fiqh. Damascus: Dār Al-Fikr Al-Arabi.

Ahmad, Waqar, and Venetia Evergeti. 2010. The making and representation of Muslim identity in Britain: Conversations with British Muslim 'elites'. Ethnic and Racial Studies 33: 1697-717. [CrossRef]

Ahmed, Abdul-Azim. 2019. Conceptualising Mosque Diversity. Journal of Muslims in Europe 8: 138-58. [CrossRef]

Akhter, Muhammad Wajid. 2017. Mosque: Back to the Future. MuslimMatters. December 4. Available online: https://muslimmatters. org/2017/12/04/mosque-back-to-the-future/ (accessed on 18 December 2020).

Al-Astewani, Amin. 2019. Loci of Leadership: The Quasi-Judicial Authority of Shariah Tribunals in the British Muslim Community. Religions 10: 406. [CrossRef]

Al-Azami, Usaama. 2019. Abdullāh bin Bayyah and the Arab Revolutions: Counter-revolutionary Neo-traditionalism's Ideological Struggle against Islamism. The Muslim World 109: 343-61. [CrossRef]

Al-Buhuti, Mansur. 2002. al-Rawd al-Murbi' bi Sharh Zad al-Mustaqni' Mukhtasar al-Muqni' fi Fiqh Imam al-Sunnah Ahmad Ibn Hanbal. Beirut: Dar al-Kutub al-Ilmiyyah'.

Al-Buti, Said Ramadan. 2006. The Jurisprudence of the Prophetic Biography \& A Brief History of the Rightly Guided Caliphs. Damascus: Dar Al-Fikr.

Al-Ghazall, Abu Hamid. 1937. Al-Mustasfa Min Ilm al-Usul. Cairo: Al-Maktabali al-Tijariyyah.

Ali, Sundas. 2015. British Muslims in Numbers: A Demographic, Socio-Economic and Health Profile of Muslims in Britain Drawing on the 2011 Consensus. London: Muslim Council of Britain Research and Documentation Committee.

Al-Kasani, Alaa Al-Din. 1986. Badaai Us Sanaai. Beirut: Dar al-Kutub al-Ilmiah.

Al-Shafi'i, Mohammad ibn Idris. 1940. Ar-Risāla. Cairo: Maktaba Moḥammad Al-Bānī.

Al-Shatibi, Abu Ishaq. 1997. Al-Muwā̄agāt fi Usul al-Sharī’ah. Beirut: Dār al-Kutub al-‘llmiyyah.

Al-Suyuti, Jalāl Al-Dīn . 1997. Al-Ashbāh wa'l Naẓā'ir. Makkah al-Mukarramah: Maktabah Nizār Muṣtafā Al-Bāz.

72 See for example (Wifaqul Ulama 2020d).

73 See (Harley 2020; Rodger 2020; Community Legal Education 2020). 
Al-Yaqoubi, Mohammad. 2016. Seeking Knowledge-The Methodology \& The Etiquette. In Sacred Knowledge. New York: Columbia University Press.

Amasha, Muhammad. 2020. The UAE-Sponsored "Islams": Mapping the Terrain. Fairfax: Maydan.

Amin, Hira. 2019. British Muslims Navigating between Individualism and Traditional Authority. Religions 10: 354. [CrossRef]

Ansari, Humayun. 2004. The Infidel within: Muslims in Britain Since 1800. London: Hurst \& Company.

Arif, Yasmeen. 2020. "Our doors are open, there's nothing to hide" Muslim Transparency in Securitized Britain. International Journal of Post Colonial Studies, 1-18. [CrossRef]

Asad, Talal. 1990. Multiculturalism and British Identity in the Wake of the Rushdie Affair. Politics and Society 18: 455-80. [CrossRef]

Bacon, Francis. 1636. A Collection of Some Principal Rules and Maximes of the Common Lawes of England. London: J. More.

BAILII. 2020. Hussain, R (on the Application of) v Secretary of State for Health \& Social Care (Rev 1) [2020] EWHC 1392 (Admin) (21 May). Available online: https:/ / www.bailii.org/ew/cases/EWHC/Admin/2020/1392.html (accessed on 18 December 2020).

BBC News. 2020a. Coronavirus: Widespread Transmission in UK 'Highly Likely'. March 2. Available online: https://www.bbc.co.uk/ news/uk-51700604 (accessed on 18 December 2020).

BBC News. 2020b. 'You Must Stay at Home' UK Public Told. Available online: https://www.bbc.com/news/live/world-52000039 (accessed on 18 December 2020).

BBC News. 2020c. Coronavirus: PM Says Everyone Should Avoid Office, Pubs and Travelling. Available online: https://www.bbc.com/ news/uk-51917562 (accessed on 18 December 2020).

BBSI. 2020a. About Us. Available online: http:/ /www.bbsi.org.uk/about-us/ (accessed on 18 December 2020).

BBSI. 2020b. Council Memebrs. Available online: http:/ / www.bbsi.org.uk/members/ (accessed on 18 December 2020).

BBSI (British Board of Imams and Scholars). 2020c. UK Community Briefing Paper for Imams, Mosques, and Madrasas for the Coronavirus Pandemic. Vancouver: BBSI.

Bowen, John. 2013. Sanctity and Shariah: Two Islamic Modes of Resolving Disputes in Todays England. In Religion in Disputes: Pervasiveness of Religious Normativity in Disputing Process. Edited by Franz von Benda. London: Palgrave Macmillan, pp. 129-30.

British Islamic Medical Association. 2020a. Available online: https:/ / www.britishima.org/ (accessed on 18 December 2020).

British Islamic Medical Association. 2020b. An Open Letter to the Muslim Community. Available online: https://www.britishima.org/ covid-open-letter-to-muslim-community / (accessed on 18 December 2020).

Broom, Herbert. 1874. A Selection of Legal Maxims. Chicago: Johnson Publishers.

Brown, Nathan. 2011. Post-Revolutionary al-Azhar. New York: Carnegie Endowment for International Peace.

Burford, Alison. 2012. Social Media and Political Participation: The Case of the Muslim Council of Britain. Ph.D. dissertation, Colarado State University, Fort Collins, CO, USA.

Burhanpuri, Nizaam Al-Din. 1991. Al-Fatawa Al-Hindiyyah. Beirut: Dar Al-Fikr.

Chitwood, Ken. 2020. Hajj Cancellation Due to Coronavirus Is Not the First Time Plague Has Disrupted This Muslim Pilgrimage. The Conversation. April 23. Available online: https://theconversation.com/hajj-cancellation-due-to-coronavirus-is-not-the-first-timeplague-has-disrupted-this-muslim-pilgrimage-135900 (accessed on 18 December 2020).

Coke, Edward. 1832. Institutes of the Laws of England. J. \& W.T. Clarke, Saunders \& Benning; A. Maxwell; etc.

Community Legal Education. 2020. Available online: https:/ / www.clevideos.co.uk/ (accessed on 18 December 2020).

Cownie, Fiona, Anthony Bradney, and Mandy Burton. 2003. English Legal System in Context. London: LexisNexis UK.

Darul Qasim. 2020a. Shaykh Mohammed Amin Kholwadia. Leadership. Available online: https://darulqasim.org/about-us/ leadership/ (accessed on 18 December 2020).

Darul Qasim. 2020b. Our Mission \& Method. Available online: https:/ / darulqasim.org/about/ (accessed on 18 December 2020).

Darul Qasim. 2020c. Ulama Coronavirus Declaration. Available online: https://darulqasim.org/wp-content/uploads/2020/03/ Ulama-Coronavirus-Declaration-3_13_2020.pdf (accessed on 18 December 2020).

Elahi, Farah, and Omar Khan. 2017. Islamophobia: Still A Challenge for Us All. London: Runnymede Trust.

Essential Islam. 2019. Available online: https://twitter.com/sufismo/status/1125540303648243714 (accessed on 18 December 2020).

Finnis, John. 2011. Natural Law and Natural Rights. Oxford: Oxford University Press.

Forte, David. 1978. Islamic Law: The Impact of Joseph Schacht. LA Int'l E Comp. L. Ann. 1: 1.

Furber, Musa. 2013. The Ultimate Conspectus. Kuala Lumpur: Islamosaic.

Furber, Musa. 2016. The Accessible Conspectus. Kuala Lumpur: Islamosaic.

Gilliat-Ray, Sophie. 2005. Closed Worlds: (Not) Accessing Deobandi'dar ul-uloom'in Britain. Fieldwork in Religion 1: 7-33. [CrossRef]

Gilliat-Ray, Sophie, and Riyaz Timol. 2020. Introduction: Leadership, Authority and Representation in British Muslim Communities. Religions 11: 559. [CrossRef]

Githens-Mazer, Jonathan, and Robert Lambert. 2010. Islamophobia and Anti-Muslim Hate Crime: A London Case Study. Exeter: University of Exeter, European Muslim Research Centre.

Guidance Hub. 2020. About Guidance Hub. Available online: https://www.guidancehub.org/about-us.html (accessed on 18 December 2020).

Hardaker, Glenn. 2012. An insight into Islamic pedagogy at the University of al-Qarawiyyin. Multicultural Education $\mathcal{E}$ Technology Journal 6. [CrossRef] 
Harley, Nicky. 2020. British mosque turned into a coronavirus hospice to support efforts to fight the pandemich. The National. April 1. Available online: https:/ / www.thenationalnews.com/world/british-mosque-turned-into-a-coronavirus-hospice-to-supportefforts-to-fight-the-pandemic-1.1000298 (accessed on 18 December 2020).

Harris, Phil. 2007. Law in Context: An Introduction to Law. Cambridge: Cambridge University Press.

Hopkins, Peter. 2009. Muslims in Britain: Race, Place and Identities: Race, Place and Identities. Edinburgh: Edinburgh University Press. Ibn Abidin, Muhammad. 1994. Rad al-Mukhtar ala Dar al-Mukhtar. Beirut: Dar al-Kutub al-Ilmiah.

Ibn Taymiyyah, Ahmed. 2004. Majmoo' Al fatawa. al-Riyāḍ: Maktabatu' Al-Malik Fahd Al Wataniyyah.

Islam21c.com. 2020a. Author Archives: Shaikh (Dr) Haitham Al-Haddad. Available online: https://www.islam21c.com/author/ shaikhhaithamal-haddad/ (accessed on 18 December 2020).

Islam21c.com. 2020b. Sh Haitham: How to Pray During a Lockdown-Coronavirus. Posted by Shaikh (Dr) Haitham Al-Haddad. Available online: https://www.islam21c.com/islamic-law/sh-haitham-how-to-pray-during-a-coronavirus-lockdown/ (accessed on 18 December 2020).

Islam21c.com. 2020c. Closing Mosques-Islamic Justifications for Coronavirus Lockdowns. Posted by: Shaykh (Dr) Sajid Umar. Available online: https:/ / www.islam21c.com/islamic-law/closing-mosques-islamic-justifications-for-coronavirus-lockdowns / (accessed on 18 December 2020).

Islamic Portal. 2020a. About. Available online: https:/ / islamicportal.co.uk/about/ (accessed on 18 December 2020).

Islamic Portal. 2020b. Coronavirus: Should Masjids Close? Available online: https://islamicportal.co.uk/coronavirus-should-masjidsclose/ (accessed on 18 December 2020).

Kamali, Mohamad. 1991. Principles of Islamic Jurisprudence. Cambridge: Islamic Texts Society.

Kamali, Mohammad. 1999. Maqāṣid Al-Sharī'ah ": The Objectives of Islamic Law. Islamic Studies 38: 193-208.

Kamali, Mohammad. 2008. Qawa 'id al-figh: The Legal Maxims of Islamic Law. Chicago: The Association of Muslim Lawyers.

Keller, Nuh. 1997. Reliance of the Traveller. Beltsville: Amana Publications.

Keller, Nuh. 2003. Al-Maqasid. Beltsville: Amana Publications.

Khan, Harun, Hassan Joudi, and Zahraa Ahmed. 2020. The Muslim Council of Britain: Progressive Interlocutor or Redundant Gatekeeper? Religions 11: 473. [CrossRef]

Klausen, Jytte. 2005. The Islamic Challenge: Politics and Religion in Western Europe. Oxford: Oxford University Press.

Littler, Mark. 2011. Number of Registered Places of Worship (England and Wales), 1999-2009. Data from General Register Office (2008-2009) and National Statistics Series FM2 (1999-2007). Manchester: University of Manchester.

MCB. 2020. MCB Calls for the Suspension of Congregational Activities at UK Mosques and Islamic Centres. March 16. Available online: https://mcb.org.uk/press-releases / mcb-calls-for-the-suspension-of-congregational-activities-at-uk-mosques-andislamic-centres / (accessed on 18 December 2020).

McLoughlin, Sean. 1998. The mosque-centre, Community-mosque: Multi-functions, Funding and the Reconstruction of Islam in Bradford. Scottish Journal of Religious Studies 19: 211-28.

Mohammad, Amjad. 2013. Muslims in Non-Muslim Lands: A Legal Study with Applications. Cambridge: Islamic Texts Society.

Nielsen, Jorgen. 1992. Muslims in Western Europe. Edinburgh: Edinburgh University Press.

Oldham Evening Chronicle. 2020. Boosting Awareness of Bowel Cancer Screening Services. Available online: https:/ /www.oldhamchronicle.co.uk/news-features/153/lifestyle-health/118274/boosting-awareness-of-bowel-cancer-screening-services (accessed on 22 December 2020).

O'Sullivan, Jack. 2001. If you hate the west, emigrate to a Muslim country. The Guardian. October 8. Available online: https: //www.theguardian.com/world/2001/oct/08/religion.uk (accessed on 18 December 2020).

Pędziwiatr, Konrad. 2007. Creating new discursive arenas and influencing the policies of the state: The case of the Muslim Council of Britain. Social Compass 54: 267-80. [CrossRef]

Pemberton, Kelley. 2009. An Islamic Discursive Tradition on Reform as Seen in the Writing of Deoband's Mufti Muhammad Taqi Usmani. The Muslim World 99: 452. [CrossRef]

Peterson, Kerry. 2003. Socio-Legality: An Odyssey of Ideas and Context. Alexandria: The Federation Press.

Pulkkinen, Tomi. 2017. Book Review: Refuting ISIS. History in the Making. CSUSB Scholarworks 10: 14.

Qureshi, Jawad. 2012. The Discourses of the Damascene Sunni Ulama during the 2011 Revolution. Syria Studies 4: 1-59.

Radcliffe, Liat. 2004. A Muslim lobby at Whitehall? Examining the role of the Muslim minority in British foreign policy making. Islam and Christian Muslim Relations 15: 365-86. [CrossRef]

Rahman, Hasib, Jamie Bartlett, and Jen Lexmond. 2010. Engaging Mosques: A Demos and Minab Toolkit for Involving Young People. London: Demos.

Reetz, Dietrich. 2007. The Deoband Universe: What makes a transcultural and transnational educational movement of Islam? Comparative Studies of South Asia, Africa and the Middle East 27: 139-59. [CrossRef]

Rodger, James. 2020. Amir Khan Offers £5 Million Wedding Venue to NHS for Coronavirus Treatment. BirminghamLive. March 25. Available online: https://www.birminghammail.co.uk/news/showbiz-tv/amir-khan-offers-5million-wedding-17982395 (accessed on 18 December 2020).

Sacred Knowledge. 2020. About Us. Available online: https:/ / sacredknowledge.co.uk/about-us/ (accessed on 18 December 2020).

Sayyid, Salmaan. 2014. A Measure of Islamophobia. Islamophobia Studies Journal 2: 10-25. [CrossRef]

SeekersGuidance. 2020a. Available online: https://seekersguidance.org/ (accessed on 18 December 2020). 
SeekersGuidance. 2020b. About Us. Available online: https:/ / seekersguidance.org/about-us / (accessed on 18 December 2020).

SeekersGuidance. 2020c. Guidance on the Coronavirus \& Attending the Mosque. Available online: https://seekersguidance.org/ answers/general-counsel/guidance-on-the-coronavirus-attending-the-mosque/ (accessed on 18 December 2020).

SeekersGuidance. 2020d. The Shafi' i School on Friday Prayer and Congregational Prayer During Epidemics. Available online: https:/ / seekersguidance.org/articles/knowledge/the-shafi\%CA\%BFi-school-on-jumu\%CA\%BFah-and-congregationalsalah-during-epidemics/ (accessed on 18 December 2020).

SeekersGuidance. 2020e. Can I Perform Friday Prayer (Jum'a) at Home During the Coronavirus Pandemic? Available online: https:/ / seekersguidance.org/answers/hanafi-fiqh/can-i-perform-friday-prayer-juma-at-home-during-the-coronavirus-pandemic/ (accessed on 18 December 2020).

Sidat, Harun. 2018. Between tradition and transition: An Islamic seminary, or Dar al-Uloom in modern Britain. Religions 9: 314. [CrossRef]

Siddiqi, Bulbul. 2018. Becoming 'Good Muslim'. Berlin/Heidelberg: Springer.

Stein, Peter. 1966. Regulae Iuris: From Juristic Principles to Legal Maxims. Edinburgh: Edinburgh University Press.

Summary of the Coronavirus Ulama and Medical Professionals' Summit. 2020. Available online: https://mawaridlifestyle.com/wpcontent/uploads/2020/03/Statement-of-senior-UK-scholars-on-Coronavirus-and-Masjids-Urdu-and-English.pdf (accessed on 18 December 2020).

Tamanaha, Brian. 2001. A General Jurisprudence of Law and Society. Oxford: Oxford University Press.

The Islamic Human Rights Commission. 2020a. About Us. Available online: https://www.ihrc.org.uk/about/about-us / (accessed on 18 December 2020).

The Islamic Human Rights Commission. 2020b. Faisal Bodi's Blog. Available online: https://www.ihrc.org.uk/category/blogs/faisalbodis-blog/ (accessed on 18 December 2020).

The Islamic Human Rights Commission. 2020c. Safeguarding Lives and Health Takes Precedence over Congregational Prayers. Available online: https:/ / www.ihrc.org.uk/blogs/faisal-bodis-blog/25369-safeguarding-lives-and-health-takes-precedenceover-congregational-prayers / (accessed on 18 December 2020).

The Islamic Human Rights Commission. 2020d. Reporting Muslims and Coronavirus. A complaint to the BBC. Available online: https:/ / www.ihrc.org.uk/activities/alerts/26467-reporting-muslims-and-coronavirus-a-complaint-to-the-bbc/ (accessed on 18 December 2020).

Timol, Riyaz. 2019. Structures of Organisation and Loci of Authority in a Glocal Islamic Movement: The Tablighi Jama'at in Britain. Religions 10: 573. [CrossRef]

Timol, Riyaz. 2020a. Ethno-religious socialisation, national culture and the social construction of British Muslim identity. Contemporary Islam 14: 331-60. [CrossRef]

Timol, Riyaz. 2020b. Mosque closures and religious authority in the British Muslim community amidst COVID-19. Journal of British Muslim Studies 3. Available online: https:/ / www.britishmuslimstudies.com/post/mosque-closures-and-religious-authority-inthe-british-muslim-community-amidst-covid-19 (accessed on 18 December 2020).

Twining, William. 1997. Law in Context: Enlarging a Discipline. Oxford: Oxford University Press.

UAE Council for Fatwa. 2020. Pertaining to the Rulings of Performing Congregational Rites in Light of the Spread of COVID-19 (Coronavirus Disease). Available online: https://sandala.org/wp-content/uploads/2020/03/Fatwa-11-COVID-19.pdf (accessed on 18 December 2020).

Waliullāh Al-Dihlawi, Ahmed. 2005. Hujatullāh Al-Bālighah. Beirut: Daraljeel.

Wifaqul Ulama. 2020a. Available online: https://www.wifaqululama.co.uk/ (accessed on 18 December 2020).

Wifaqul Ulama. 2020b. About Wifaqul Ulama. Available online: https://www.wifaqululama.co.uk/about-us/ (accessed on 18 December 2020).

Wifaqul Ulama. 2020c. Muharram in a Nutshell. August 16. Available online: https://www.wifaqululama.co.uk/muharram/ (accessed on 18 December 2020).

Wifaqul Ulama. 2020d. Coronavirus briefing for Mosques. Available online: https://www.wifaqululama.co.uk/covid19/ (accessed on 18 December 2020).

Winfield, Percy. 1928. Public Policy in the English Common Law. Harvard Law Review 42: 78. [CrossRef]

YouTube. 2020. COVID 19 and Friday Prayers: Shaykh Muhammad Al-Yaqoubi. Available online: https://www.youtube.com/watch? $\mathrm{v}=\mathrm{zAkrOzhKRQw}$ (accessed on 18 December 2020).

Zaimeche, Salah. 2002. Education in Islam: The Role of the Mosque. London: Foundation for Science Technology and Civilization. 